MATEC Web of Conferences 53, 01012 (2016)

DOI: $10.1051 /$ matecconf/20165301012

(C) Owned by the authors, published by EDP Sciences, 2016

\title{
Ventilated Facades: Insulation Materials of Different Manufacturers
}

\author{
Alexandra Shatornaya $^{1, a}$, Maria Chislova ${ }^{1}$, Anna Chislova ${ }^{1}$, Marina Drozdetskaya ${ }^{1}$ and Daria Trubina ${ }^{1}$ \\ ${ }^{1}$ Peter the Great St.Petersburg Polytechnic University., 195251, St. Petersburg, Russian Federation
}

\begin{abstract}
The article analyzes the various manufacturers of thermal insulation materials that are used in hinged ventilated facades and there is a comparison them by the same criteria for identifying the advantages and disadvantages of their using in civil engineering. In the article there are the results of the carrying out calculations of wall construction with ventilated facade to resistance of heat transfer by using materials from different manufacturers for identical wall construction. As a result, has chosen material, with the best price, energy efficiency and safety of use.
\end{abstract}

\section{Introduction}

The Law N 261-FZ [1] was passed in 2009 to increase in the requirements to the energy efficiency of buildings and stimulation manufacturers in the market of thermal insulation materials. Researches show that $45 \%$ of the heat is lost through the enceinte walls [2-5]. The system of hinged ventilated facades (HVF) is used to improve the energy efficiency of buildings, and high-quality thermal insulation materials take on enormous importance in such type of systems. The choice of material affects the heat losses of the building

\section{Materials and Methods}

\subsection{Studding of literature about the subject}

In modern engineering, more attention is paid to the study of thermalphysic properties of enclosure constructions, their influence on the energy efficiency of buildings, severization requirements for them. These kinds of researches were conducted by Gagarin V.G. [6], A.S. Gorshkov [7,8].

The system of ventilated facades had been studied comprehensively in articles [9-12], and also the fire safety of such systems [13], the models of their work during the exploitation[14-16], and the construction of energy efficient houses $[17,18]$.

Comparison of different modern insulating materials and study of their properties were carried out by Gorelik P.I., Zolotova Y.S. [19], Vatin N.I. [20], in works [21-22] there were compared the individual characteristics of materials. In Berdyugin's I.A. research [23] was made comparative analysis of glass wool and stone wool insulation as thermal covering.

${ }^{\mathrm{a} C}$ Corresponding author, e-mail: alexandrashatornaya@gmail.com 
In previously published articles describe only the variety of existing thermal insulation materials, their properties and the field of application. However, a comparative analysis of the materials, that are used for the hinged ventilated facades (HVF), from the specific manufacturers for their actual properties and prices have never been made earlier.

\subsection{Statement of Purpose of research}

To carry out a comparative analysis of market of thermal insulation materials with the purpose the most favorable ratio between energy efficiency and economic feasibility for using them in hinged ventilated facade systems.

Owing from the objectives it is necessary to solve a number of problems:

1) Elucidate the market of modern insulating materials in Russia, to establish the most used types of thermal insulation materials for the HVF, their advantages and disadvantages.

2) Calculate total the resistance of heat loss for the enceinte wall with ventilated facade system using the selected thermal insulation materials.

3) Compile a comparison table of heaters for organizing data that was made during the research. Important criteria are: safety of use, thermal conductivity, and the cost of production.

4) Perform a final analysis of the results; identify the most energy-efficient, economical and safe to use insulation material.

\subsection{Market Research of modern insulating materials and manufacturers}

It should pay attention in choosing the material to the safety from the standpoint of fire safety (ignitability, toxicity) and ecologically cleanses. Investigation of these criteria is necessary for the construction of high-quality energy-efficient structures. There are several varieties of mineral wools: rock wool, glass wool and slag wool.

Slag wool is produced from blast-furnace slag, but can't find extensive use in Russia because of the low maintenance properties.

Glass wool is cheaper, less volume, occupied less space during transportation. A disadvantage of using it in the HVF is the flexibility, elasticity and low imporosity, it can lead to the shrinkage loss and the need to use a windproof film. However, glass wool creates less stress on the structure, because of low imporosity.

Rock wools advantages are: nonsusceptibility, deformations almost complete absence of changes, application temperature $(1000 \mathrm{C})$ higher than that of glass wool $(400 \mathrm{C})$. The stone wool is not used toxic substances. The main drawback - the price is above the glass wool.

We have considered thermal insulation materials for the HVF system from well-known manufacturers such as ISOVER, ROCKWOOL, URSA, IZOROCK, Technonikol, Paroc, Ecover and

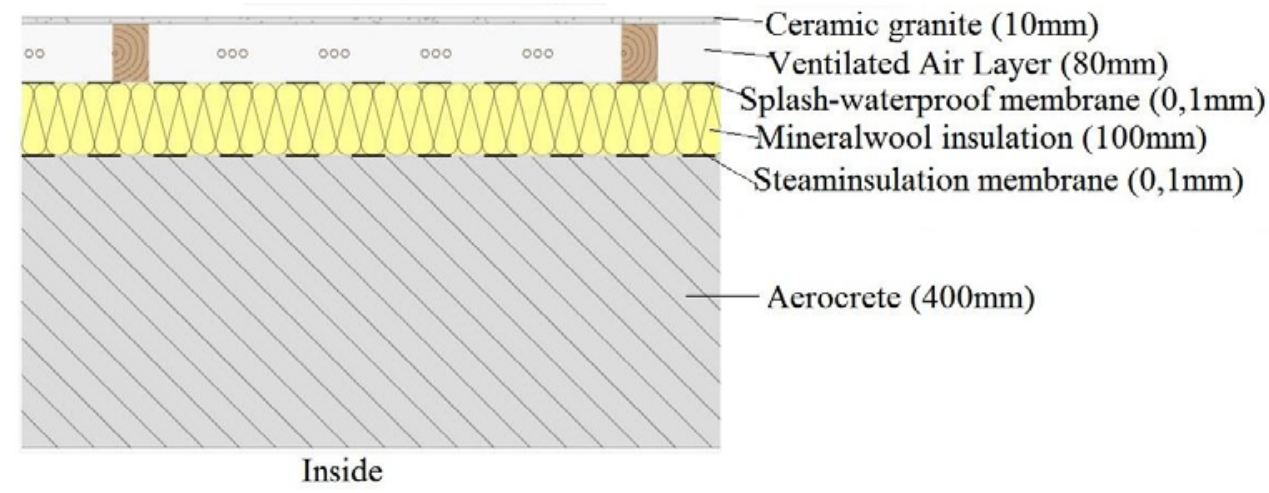

Figure 1. Construction of ventilated facade 
others. As a result was chosen one material for each type of manufacturer. All insulation materials are non-combustible. To analysis of the data classification was compiled in comparative table (Table 1).

For calculations there was used the identical structure of the hanging ventilated facades: Aerated Concrete $(400 \mathrm{~mm})$, vapor barrier sheet, insulation $(100 \mathrm{~mm})$, house wrap sheet, ventilated air layer $(80 \mathrm{~mm})$, porcelain stoneware slabs $(10 \mathrm{~mm})$ (Fig. 1).

The calculation is performed in accordance with the requirements of SNIP 23-02-2003 [24], SNIP 1.23.09, by the method of SP-23-1001-2004 for the North-West region, which is been in application condition $\mathrm{B}$. It was taken into account the thermal conductivity index $\lambda \mathrm{B}$ because thermal conductivity in operating conditions $\mathrm{B}$ has the greatest value.

For the analysis of the data was made several comparative tables.(tabl 1-3)

Table 1. Comparison of fibered glass from different manufacturers

\begin{tabular}{|c|c|c|c|}
\hline \multirow[b]{2}{*}{ Manufactor and product } & \multicolumn{3}{|c|}{ fibered glass } \\
\hline & $\begin{array}{l}\text { URSA Pure One } \\
\text { (eco-friendly } \\
\text { material) }\end{array}$ & $\begin{array}{l}\text { URSA (GEO P- } \\
\text { 30) }\end{array}$ & $\begin{array}{l}\text { ISOVER } \\
\text { (VentFasad } \\
\text { Mono) }\end{array}$ \\
\hline \multicolumn{4}{|l|}{ Main characteristics: } \\
\hline possible thickness, $[\mathrm{mm}]$ & 50,100 & $50-100$ & 50,100 \\
\hline density, $[\mathrm{kg} / \mathrm{m} 3]$ & $18-22$ & 30 & 70 \\
\hline flammability group & NF & NF & NF \\
\hline $\begin{array}{l}\text { thermal conductivity } \lambda \text { at } 10 \mathrm{C} \\
{[\mathrm{W} / \mathrm{mK}]}\end{array}$ & 0.034 & 0.032 & 0.034 \\
\hline $\begin{array}{l}\text { thermal conductivity } \lambda \text { at } 25 \mathrm{C} \\
{[\mathrm{W} / \mathrm{mK}]}\end{array}$ & 0.037 & 0.034 & 0.036 \\
\hline$\lambda$ upon conditions $\mathrm{A}[\mathrm{W} / \mathrm{mK}]$ & 0.039 & 0.036 & 0.038 \\
\hline$\lambda$ upon conditions $\mathrm{B}[\mathrm{W} / \mathrm{mK}]$ & 0.041 & 0.039 & 0.04 \\
\hline $\begin{array}{l}\text { Thermal resistance of ventilated facade } \\
\text { construction, }[\mathrm{m} 2 * \mathrm{C} / \mathrm{W}]\end{array}$ & 3.82 & 3.94 & 3.88 \\
\hline Heat loss per heating season $[\mathrm{kWh}]$ & 28.53 & 27.63 & 28.08 \\
\hline $\mathrm{m} 3$ in package & 0.45 & 0.75 & 0.493 \\
\hline cost for $1 \mathrm{~m} 3$ & 1900 & 2736 & 4746 \\
\hline \multicolumn{4}{|l|}{ Additional characteristics: } \\
\hline $\begin{array}{l}\text { Water absorption ability at short-term } \\
\text { and not full immersion for } 24 \text { hours, } \\
\text { no more, }[\mathrm{kg} / \mathrm{m} 2]\end{array}$ & 1 & 1 & 1 \\
\hline $\begin{array}{l}\text { vapor permeability, no less } \\
{\left[\mathrm{mg} /\left(\mathrm{m}^{*} \mathrm{~h} * \mathrm{~Pa}\right)\right]}\end{array}$ & 0.51 & 0.59 & - \\
\hline operating temperature $[\mathrm{C}]$ & $\begin{array}{l}\text { from }-60 \text { to } \\
+220\end{array}$ & from -60 to +290 & - \\
\hline
\end{tabular}

Table 2. Comparison of mineral wool from different manufacturers 


\begin{tabular}{|c|c|c|c|c|c|}
\hline \multirow[b]{2}{*}{ Manufactor and product } & \multicolumn{5}{|c|}{ rock-wool } \\
\hline & $\begin{array}{l}\text { Rock- } \\
\text { wool } \\
\text { (Venti } \\
\text { Butts) }\end{array}$ & $\begin{array}{l}\text { Techno- } \\
\text { Nikol } \\
\text { (techno- } \\
\text { vent } \\
\text { Optima) }\end{array}$ & $\begin{array}{l}\text { Paroc } \\
\text { WAS } 35\end{array}$ & $\begin{array}{l}\text { Isoroc } \\
\text { Isovent }\end{array}$ & $\begin{array}{l}\text { ISOVE } \\
\mathrm{R} \\
\text { (Venti) }\end{array}$ \\
\hline \multicolumn{6}{|l|}{ Main characteristics: } \\
\hline possible thickness, $[\mathrm{mm}]$ & 50,100 & $100 \mathrm{Mм}$ & $30-150$ & $40-160$ & $\begin{array}{l}50 \\
100\end{array}$ \\
\hline density, $[\mathrm{kg} / \mathrm{m} 3]$ & 90 & $81-99$ & 85 & 90 & $82-103$ \\
\hline flammability group & $\mathrm{NF}$ & NF & $\mathrm{NF}$ & NF & NF \\
\hline thermal conductivity $\lambda$ at $10 \mathrm{C}[\mathrm{W} / \mathrm{mK}]$ & 0.035 & - & 0.033 & 0.034 & 0.035 \\
\hline $\begin{array}{l}\text { thermal conductivity } \lambda \text { at } 25 \mathrm{C} \\
{[\mathrm{W} / \mathrm{mK}]}\end{array}$ & 0.037 & 0.036 & 0.034 & 0.036 & - \\
\hline$\lambda$ upon conditions $\mathrm{A}[\mathrm{W} / \mathrm{mK}]$ & 0.038 & 0.038 & 0.04 & 0.039 & 0.038 \\
\hline$\lambda$ upon conditions $\mathrm{B}[\mathrm{W} / \mathrm{mK}]$ & 0.04 & 0.04 & 0.043 & 0.041 & 0.039 \\
\hline $\begin{array}{l}\text { Thermal resistance of ventilated facade } \\
\text { construction, }[\mathrm{m} 2 * \mathrm{C} / \mathrm{W}]\end{array}$ & 3.88 & 3.88 & 3.7 & 3.82 & 3.88 \\
\hline Heat loss per heating season [kWh] & 28.08 & 28.08 & 29.41 & 28.53 & 28.08 \\
\hline m3 in package & 0.18 & 0.216 & 0.216 & 0.2 & 0.216 \\
\hline cost for $1 \mathrm{~m} 3$ & 3790 & 2764 & 3754 & 3920 & 3983.6 \\
\hline \multicolumn{6}{|l|}{ Additional characteristics: } \\
\hline $\begin{array}{l}\text { Water absorption ability at short-term } \\
\text { and not full immersion for } 24 \text { hours, no } \\
\text { more, }[\mathrm{kg} / \mathrm{m} 2]\end{array}$ & 1 & $\begin{array}{l}1,5 \% \text { in } \\
\text { volume }\end{array}$ & 1 & 1 & 1 \\
\hline $\begin{array}{l}\text { vapor permeability, no less } \\
{[\mathrm{mg} /(\mathrm{m} * \mathrm{~h} * \mathrm{~Pa})]}\end{array}$ & 0.3 & 0.3 & 1 & - & 0.3 \\
\hline $\begin{array}{l}\text { Compressive strength at } 10 \% \\
\text { deformation, no less }[\mathrm{kPa}]\end{array}$ & 20 & 12 & - & 20 & 20 \\
\hline operating temperature $[\mathrm{C}]$ & - & - & - & - & - \\
\hline $\begin{array}{l}\text { organic matter content, no more than } \\
{[\%]}\end{array}$ & - & 3 & - & 4 & - \\
\hline
\end{tabular}


Table.3. Comparison of bazalt wool from different manufacturers

\begin{tabular}{|c|c|c|c|c|c|}
\hline \multirow[b]{2}{*}{ Manufactor and product } & \multicolumn{5}{|c|}{ basalt fibre plates } \\
\hline & $\begin{array}{l}\text { Tekhno- } \\
\text { Nikol } \\
\text { Rocklife }\end{array}$ & $\begin{array}{l}\text { Termo- } \\
\text { bazalt } \\
\text { PR- } 80 \\
\text { (VENTI) }\end{array}$ & $\begin{array}{l}\text { Tizol } \\
\text { EURO- } \\
\text { Vent }\end{array}$ & $\begin{array}{l}\text { Ecover } \\
\text { Vent- } \\
\text { Facade }\end{array}$ & $\begin{array}{l}\text { Termo- } \\
\text { life } \\
\text { EcoVe } \\
\text { nt } \\
\text { Facade }\end{array}$ \\
\hline \multicolumn{6}{|l|}{ Main characteristics: } \\
\hline possible thickness, $[\mathrm{mm}]$ & 50,100 & 50,100 & $40-200$ & $30-250$ & $50-200$ \\
\hline density, [kg/m3] & $30-40$ & 80 & 80 & 80 & 60 \\
\hline flammability group & NF & NF & NF & NF & $\mathrm{NF}$ \\
\hline thermal conductivity $\lambda$ at $10 \mathrm{C}[\mathrm{W} / \mathrm{mK}]$ & - & 0.033 & 0.034 & 0.035 & 0.036 \\
\hline thermal conductivity $\lambda$ at $25 \mathrm{C}[\mathrm{W} / \mathrm{mK}]$ & 0.039 & 0.035 & 0.036 & 0.036 & - \\
\hline$\lambda$ upon conditions $\mathrm{A}[\mathrm{W} / \mathrm{mK}]$ & 0.04 & 0.041 & 0.038 & 0.038 & 0.04 \\
\hline$\lambda$ upon conditions $\mathrm{B}[\mathrm{W} / \mathrm{mK}]$ & 0.041 & 0.044 & 0.04 & 0.039 & 0.044 \\
\hline $\begin{array}{l}\text { Thermal resistance of ventilated facade } \\
\text { construction, }[\mathrm{m} 2 * \mathrm{C} / \mathrm{W}]\end{array}$ & 3.82 & 3.65 & 3.88 & 3.94 & 3.65 \\
\hline Heat loss per heating season $[\mathrm{kWh}]$ & 28.53 & 29.83 & 28.08 & 27.63 & 29.83 \\
\hline $\mathrm{m} 3$ in package & 0.432 & 0.25 & 0.2 & 0.36 & 0.3 \\
\hline cost for $1 \mathrm{~m} 3$ & 1211 & 2792 & 2320 & 2681 & 2350 \\
\hline \multicolumn{6}{|l|}{ Additional characteristics: } \\
\hline $\begin{array}{l}\text { Water absorption ability at short-term } \\
\text { and not full immersion for } 24 \text { hours, no } \\
\text { more, }[\mathrm{kg} / \mathrm{m} 2]\end{array}$ & $\begin{array}{l}2 \% \text { in } \\
\text { volume }\end{array}$ & 1.5 & 1 & 0.75 & $\begin{array}{l}2 \% \text { in } \\
\text { volume }\end{array}$ \\
\hline $\begin{array}{l}\text { vapor permeability, no less }[\mathrm{mg} /( \\
\mathrm{m} * \mathrm{~h} * \mathrm{~Pa})]\end{array}$ & 0.3 & 0.37 & 0.3 & - & 0.3 \\
\hline $\begin{array}{l}\text { Compressive strength at } 10 \% \\
\text { deformation, no less }[\mathrm{kPa}]\end{array}$ & - & 20 & 18 & 16 & 12 \\
\hline operating temperature $[\mathrm{C}]$ & $\begin{array}{l}\text { from }-60 \\
\text { to }+200\end{array}$ & To +650 & To +400 & $\begin{array}{l}\text { More } \\
1000\end{array}$ & - \\
\hline $\begin{array}{l}\text { organic matter content, no more than } \\
{[\%]}\end{array}$ & 2.5 & 1.5 & - & 3.5 & 3 \\
\hline
\end{tabular}




\section{Results and discussion}

After analyzing the data of Table 1, glass wool URSA (GEO P-30) has a higher rate on the main characteristics than glass wool URSA Pure One and ISOVER. It is necessary to take into account that the material URSA Pure One is environmentally friendly and has a lower cost, but it has the highest heat loss during the heating season $(28.53 \mathrm{~kW} * \mathrm{~h})$. In this regard, we have chosen material URSA (GEO P-30), which is higher in value, but is more energy efficient in view of the high performance in all other criteria.

Next, we examined the materials of mineral wool: stone wool (Table 2) and a basalt slab (Table 3).

From Table 2, there are two differing material: Rock wool Technonikol and ISOVER. Rock wool by ISOVER manufacturer has a variouse thickness, high density, low thermal conduction of the application conditions A and B. Wool Technonikol have only one thickness, thermal conduction of the application conditions B is slightly worse. Wool of this manufacturer has the lowest cost.

Index heat leakage and heat transmission resistance is the same for bouth manufacturers. As the second most important criterion is profitability, we chose rock wool of company Technonikol.

After reviewing Table 3, it can be concluded that the basalt slab Ecover is the best in terms of heat transmission resistance, heat loss and thermal conduction of the application condition B; the material is environmentally clean and has the lowest water absorption. The cost of the Technonikol slab is the cheaper, but it loses Ecover slab in all other indicators.

For the final choice of material was made the final consisting table of three materials in one of each type of material.(table 4)

Prices of the selected materials are in the same range and depend on suppliers and the region of building, but we should note the need of using a fuel windproof membrane for glass wool that could increase the total cost of construction. HVF with using materials from URSA GEO and Ecover have the smallest heat losses during the heating season, which will save significant sum of money in highrise constructions. Ecover Material of HVF has an ecological certificate and is safe to use, so that the final choice was stopped on it.

Fig. 2 presents a distribution graph of the temperature in the construction of HVF with selected thermal insulation material.

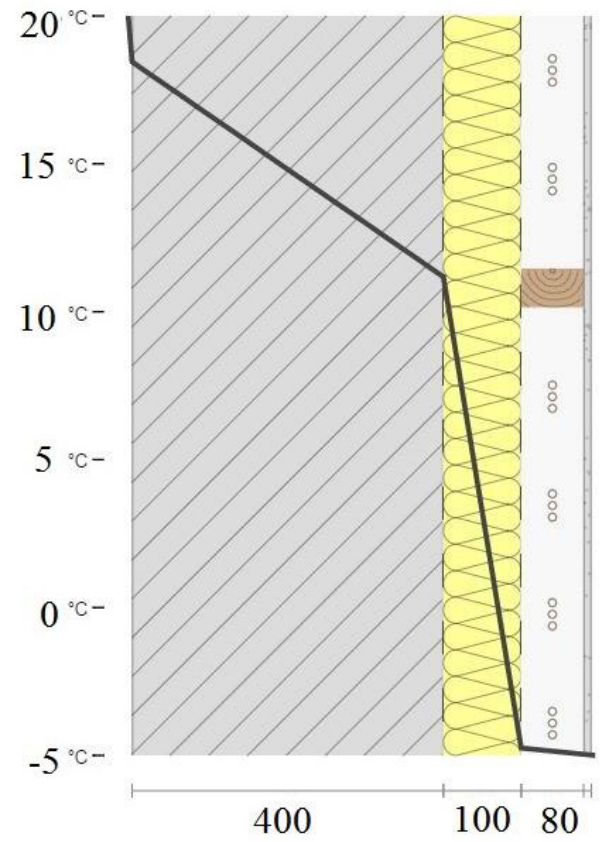

Figure 2. Distribution graph of the temperature (in ${ }^{\circ} \mathrm{C}$ ). 
Table 4. Comparison of bazalt wool from different manufacturers

\begin{tabular}{|c|c|c|c|}
\hline & fibered glass & rock-wool & $\begin{array}{l}\text { continuous } \\
\text { basalt fibre } \\
\text { plates }\end{array}$ \\
\hline Manufactor and product & $\begin{array}{l}\text { URSA (GEO П- } \\
30)\end{array}$ & $\begin{array}{l}\text { TechnoNikol } \\
\text { (TECHNOVENT } \\
\text { Optima) }\end{array}$ & $\begin{array}{l}\text { Ecover } \\
\text { VentFasad }\end{array}$ \\
\hline \multicolumn{4}{|l|}{ Main characteristics: } \\
\hline possible thickness, $[\mathrm{mm}]$ & $50-100$ & 100 & $30-250$ \\
\hline density, [kg/m3] & 30 & $81-99$ & 80 \\
\hline flammability group & $\mathrm{NF}$ & $\mathrm{NF}$ & NF \\
\hline $\begin{array}{l}\text { thermal conductivity } \lambda \text { at } 10 \\
C[\mathrm{~W} / \mathrm{mK}]\end{array}$ & 0.032 & - & 0.035 \\
\hline $\begin{array}{l}\text { thermal conductivity } \lambda \text { at } 25 \\
C[\mathrm{~W} / \mathrm{mK}]\end{array}$ & 0.034 & 0.036 & 0.036 \\
\hline$\lambda$ upon conditions $\mathrm{A}[\mathrm{W} / \mathrm{mK}]$ & 0.036 & 0.038 & 0.038 \\
\hline$\lambda$ upon conditions $B[\mathrm{~W} / \mathrm{mK}]$ & 0.039 & 0.04 & 0.039 \\
\hline $\begin{array}{l}\text { Thermal resistance of ventilated } \\
\text { facade construction, }[\mathrm{m} 2 * \mathrm{C} / \mathrm{W}]\end{array}$ & 3.94 & 3.88 & 3.94 \\
\hline Heat loss per heating season $[\mathrm{kWh}]$ & 27.63 & 28.08 & 27.63 \\
\hline $\mathrm{m} 3$ in package & 0.75 & 0.216 & 0.36 \\
\hline cost for $1 \mathrm{~m} 3$ & 2736 & 2764 & 2681 \\
\hline \multicolumn{4}{|l|}{ Additional characteristics: } \\
\hline $\begin{array}{l}\text { Water absorption ability at short-term } \\
\text { and not full immersion for } 24 \text { hours, } \\
\text { no more, }[\mathrm{kg} / \mathrm{m} 2]\end{array}$ & 1 & $1,5 \%$ per volume & 0.75 \\
\hline $\begin{array}{l}\text { vapor permeability, no less } \\
{[\mathrm{mg} /(\mathrm{m} * \mathrm{~h} * \mathrm{~Pa})]}\end{array}$ & 0.59 & 0.3 & - \\
\hline $\begin{array}{l}\text { Compressive strength at } 10 \% \\
\text { deformation, no less }[\mathrm{kPa}]\end{array}$ & - & 12 & 16 \\
\hline operating temperature $[\mathrm{C}]$ & from -60 to +290 & - & $\begin{array}{l}\text { More } \\
1000\end{array}$ \\
\hline
\end{tabular}




\section{Conclusion}

As a result of a comparative analysis there was made a conclusions:

In the article was explored the market of modern insulating materials for NVF systems in Russia and installed the most common insulation materials: glass wool, rock wool and basalt slabs.

According to SNIP 23-02-2003 was calculated the HVF for the heat transfer resistance by using selected heaters.

Was compiled and analyzed the comparative table of using heaters.

Basalt slabs Ecover is the most appropriate ratio of energy efficiency and price per $\mathrm{m} 3$ as compared with products from other manufacturers. It is an environmentally clean insulation. For choosing of insulation material for the HVF system recommended to use products with similar characteristics.

In the conditions of the cold climate, limited resources and rising electricity prices it becomes a priority to reduce heat loss through the enclosing wall in modern construction. Choosing of high quality insulation material is extent the energy efficiency of buildings. In today's market there is a wide range of heaters, and therefore it is important to understand exactly what criteria to consider when designing.

Savings on heating by reducing the amount of heat loss through the building structure inclosing walls should be available in terms of pay for the costs of high-quality insulation, which may be higher than with other materials. In addition, you must take into account the fire and environmental safety, which can be a determining factor in the final selection.

\section{Conflict of interests}

The authors declare that there is no conflict of interest regarding the publication of this paper.

\section{References}

1. The Law of the Russian Federation "On energy saving and on energy efficiency and on amendments to certain legislative acts of the Russian Federation" of 23.11.2009

2. N. I. Vatin, A. S. Gorshkov, D. V. Nemova, Construction of Unique Buildings and Structures Journal, 3, 8 (2013)

3. V. G. Gagarin, Journal Academia. Architecture and construction, 5, 297-305 (2009)

4. A. S. Gorshkov, D. V. Nemova, N. I. Vatin, Construction of Unique Buildings and Structures Journal, 7, 12 (2013)

5. O. I. Lobov, A. I. Ananyev, V. P. Abarykov, A. E. Sinyutin, II all-Russian scientific and technical conference: Building Thermophysics and energy effective design of walling of buildings, 80-92 (2009)

6. V. G. Gagarin, II all-Russian scientific and technical conference: Building Thermophysics and energy effective design of walling of buildings, 33-44 (2009)

7. A.S. Gorshkov, V.I. Livchak, Construction of Unique Buildings and Structures Journal, 3, 30 (2015)

8. A. S. Gorshkov, I. A. Voilokov, II all-Russian scientific and technical conference: Building Thermophysics and energy effective design of walling of buildings, 45-48 (2009)

9. M.V. Petrochenko, K.I. Strelets, M.R. Petrichenko, E.B. Yavtushenko, Applied mechanics and materials, 672-674, 567-570 (2014)

10. M.I. Nizovtsev, A.N. Sterlygov, V.T. Belyi, Construction of Unique Buildings and Structures, 6( 33), 19-33 (2014)

11. G. M. Vasilchenko, Donbas National Academy of Civil Engineering and Architecture, 4, 203211(2013)

12. V. Bogdanovic, S. Samardzie, Architecture and Civil Engineering, 1, 57 - 68 (2004) 
13. A. P. Samar, E. J. Onokhov, O. V. Chalupova, Fire safety study of buildings shed-governmental facades, 1, 357-362 (2013)

14. Balocco C., Energy and Buildings, 34, 469-475 (2002)

15. L. Mei, D.G. Infield, U. Eicker, and V. Fux., Energy and Buildings, 32, 569-575 (2011)

16. C. Marinosci, G. Semprini, G.L. Morini, P.A. Strachan, Energy And Buildings, 43, 853-863 (2011)

17. A. Fikfak, Journal of Architecture and Urbanism, 37 (4), 257-267 (2013)

18. A. Fikfak, M.Z. Senegačnik, Glasnik SED, 48 (1-2), 2-67 (2008

19. P. I. Gorelik, Yu. S. Zolotova, Construction of Unique Buildings and Structures, 3, 18 (2014)

20. N. Vatin, A. S. Gorshkov, A. Kazimirova, K. Gureev, D. V. Nemova, JAES, 3, 207-216 (2014)

21. G. Chaykovskiy, Bachelor thesis, Mikkeli University of Applied Sciences (2010)

22. M. J. Duijve, MS Thesis, Utrecht University (2012)

23. I. A. Berdugin, Civil Engineering Journal, 1, 345-366, (2010)

24. Construction rules and regulations "Thermal protection of buildings" of 23.02.2003 